\title{
The Study of Using Introduction Themselves and Their Families Conversations in Teaching Speaking of 3rd Class Students of Elementary School
}

\author{
Veronika Unun Pratiwi $1, a^{*}$, Nurnaningsih $1, b$, and Arin Arianti $1, c$ \\ ${ }^{1}$ Department of English Education, Faculty of Teachers Training and Education, Veteran Bangun Nusantara University, Sukoharjo, 57521, Indonesia \\ a pratiwiunun@yahoo.co.id; b nurnananinx@gmail.com; c ariantiarin87@gmail.com \\ ${ }^{*}$ Corresponding Author
}

How to Cite : Pratiwi, V., U., Nurnaningsih, N., Arianti, A. (2019). The Study of Using Introduction Themselves and Their Families Conversations in Teaching Speaking of 3rd Class Students of Elementary School . International Journal for Educational and Vocational Studies, 1 (7), 800-804. DOI: https://doi.org/10.29103/ijevs.v1i7.1988

\section{ARTICLE HISTORY}

Received: 11 August 2019

Revised: 22 September 2019

Accepted: 17 October 2019

\section{KEYWORDS}

Teaching Speaking; Introduction Self and Family; Elementary School;

\begin{abstract}
Speaking skills in English is a very important skill in general communication. This skill is needed even since school age children. SD Negeri Jombor 03 Bendosari Sukoharjo is located in Jombor sub-district, Bendosari sub-district, Sukoharjo regency, which has students with relatively low English speaking ability. This is evidenced from the document a student's grade is relatively lace that obtained by the researchers through observation. The purpose of this study is to provide convenience for students of SD Negeri Jombor 03 Bendosari Sukoharjo to improve their speaking skills, especially to introduce themselves and their families. The method used by researchers is practice individually, in pairs, and in groups. This method provides an opportunity for students to be more active and expressive to express ideas, and bring up peer tutors to reduce the tension or pressure that obtained indirectly in a foreign language learning. In addition to the planned method, researchers also made use of LCD media and letter cards along with plastic boards to help students more easily absorb the material. This media was contributed quite a lot.The students feel happy, enthusiastic and more expressive in accepting the material provided.The researchers obtained the data by field observations, then the researchers made other instruments such as questionaire sheets, pretests and evaluations. The results of this study are quite significant. The students was increased by $30.66 \%$ than of the results of the pretest and posttest. This method is expected to be carried out elsewhere so that the benefits can be felt in the wider community.
\end{abstract}

This is an open access article under the CC-BY-SA license.

\section{INTRODUCTION}

SDN Jombor 03 Sukoharjo is located in the Gabusan RT 03/RW V of Jombor Village, Bendosari District, Sukoharjo Regency. This elementary school has a total of 96 students whose status is fluctuating, that is being decreased from the previous number which is more. In learning languages, especially English language learning, there are four skills of speaking that absolutely must be mastered by students, namely listening skills (listening), reading comprehension skills (reading), speaking skills (speaking), and writing skills (writing) as well as vocabulary skills and Grammar (Structure and vocabulary).

A skill will be mastered well if it is learned and practiced. Similarly, speaking skills (Speaking) need to be taught. Learning conversational skills (Speaking) good and continuous is needed given the importance of other language skills.
Speaking skill is one aspect of language that needs to be studied. Speaking skills are at least able to be a support and as a measure for individuals in learning a language and are primary in establishing communication between individuals.

Learning English in Grade 6 students at SD Negeri Jombor Sukoharjo currently requires students to be skilled in speaking in the learning process. Students are at least able to express their ideas, be able to answer questions or ask questions, express opinions, defend opinions, refute the opinions of other students, or influence other students to follow the flow of thought. However based on empirical data shows that students who have studied English are still relatively low. The learning achievements of students at SDN Jombor 03 are generally good in general, but for English lessons only a few students get good grades. The courage of students to 
advance in front of the class seems low because most of them are afraid to speak wrongly when uttering sentences in English. The problems early as this is what makes a team of researchers interested in conducting coaching mainly research on English language proficiency in this skill students introduce themselves and family in English.

The students are getting to dare to use English indeed not an easy thing. That is because they are already familiar with English as a lesson, not as an interesting language to learn. Moreover, It was added with the teacher who still focus on teaching grammar rather than communicative competence, whereas in this case Brown (2000: 266-267) argues that 1) Class goals are focused on all components of communicative competence and are not limited by grammatical or linguistic competence, 2) Language techniques are designed to include students in pragmatic, authentic language use; functional for meaningful purposes. Organizational forms of language are not the main focus but are aspects of language that make students achieve their goals these objectives, 3) The fluency and accuracy are seen as a complement to the principles underlying communication techniques. At certain times fluency can be more important than accuracy to make students meaningfully participate in the use of language, 4). In communicative classrooms, in the end, students must use language productively and receptively in context rather than practice.

In reality on the ground, it was seen that English teachers complained about the low English speaking ability of their students. This can be seen by students who speak English ineffectively and efficiently. The students showed bad habits in speaking; for example memorizing dialogue textually, speaking in intermittent rhythm, improper vocabulary placement, hesitant and imperfect utterances so difficult to understand and so on. Meanwhile, the learning plan that has been designed by the teacher was not achieved because generally students only spent time memorizing the text given by the teacher.

In addition, preliminary observations indicate that the achievement of English language teaching at SD Negeri Jombor 03 Bendosari Sukoharjo is still far from the expectations. This can be seen in the results of learning to speak students who have not been satisfactory due to internal and external constraints mentioned above. , For example, The students have experience difficulties in speaking fluently and acceptably. The ability of students who are still lacking not yet supported by efforts to use appropriate speaking techniques. Besides, students' interest and motivation to learn are also low and are not supported by the right learning media, the result of the theory absorbed by students is bad.

From the problems faced by the research team, the community agreed to conduct research to introducing themselves and families in English to students at SDN Jombor 3 Sukoharjo.

\section{METHODS}

\subsection{Types of research}

Based on the focus of this research, this type of research is a qualitative descriptive study.

\subsection{Research Subject and Time}

The subjects of this research are grade 3 students of elementary schools. This subject is considered as a beginner in learning English for the second time for them to know and learn English.

\subsection{Research Place}

There are a lot of Public Elementary Schools in Sukoharjo Regency, but the authors chose SDN Jombor 03 Bendosari as a place to conduct research.

\subsection{Data and Data Sources}

The data used in this study are in the form of simple conversation texts. While the data source is an English teacher at SDN Jombor 03 Sukoharjo along with students in grade 3 at SDN Jombor 03 Sukoharjo.

\subsection{Data collection technique}

To collect data before and after the assessment things like the following are very necessary, namely:

1 Interview

2 Observation/observation

3 Documentation method

which aims to obtain more accurate research data. If possible, data collection techniques can be combined from the three, namely interviews, observation and documentation, or called triangulation.

\subsection{Research Instruments}

In qualitative research, the main instrument is the researcher himself or a member of the research team. But in this study the main instrument is the interview conducted by interview, observation is done by check list and the documentation method is done by taking photos and recording data.

\subsection{Data Validity}

In this study the validity of the data/the validity of the data is tested by triangulation from the three data that have been obtained. Namely with the credibility test carried out by the extension of observation, increase perseverance and discussion with teammates.

\subsection{Data analysis technique}

In qualitative research, more data analysis techniques are carried out simultaneously with varied data collection and carried out continuously until the data is saturated. The 
researcher asks the informant to get the correct explanation related to the main problem of the research (in-depth interviews). The researcher makes an interpretation so that one information can be explained in relation to the other information (does not change the meaning of the informant's interpretation) whether collected through observation, interviews, and document essence. Even if necessary, the data is described, focused and then selected.

\section{RESULTS AND DISCUSSION}

\section{Results}

The skill of introducing Themselves and family using English for elementary school students is needed considering that these skills can help students communicate with others both inside and outside of school. In reality this skill is needed for elementary school students to be accepted into secondary school. A skill will be mastered well if it is learned and practiced. Learning conversational skills ( Speaking) good and continuous is needed given the importance of the other language skills. Speaking skills are one of the aspects of language that is studied in this activity. Speaking skills are at least able to be a support and as a measure for individuals in learning a language and are primary in establishing communication between individuals. The results of this activity are as follows:

The results of the evaluation of the research skills in introducing Themselves and family in English to students at SD Negeri Jombor 03 Bendosari Sukoharjo can be seen in table 3.1 as follows:

Table 1. The average of Understanding Participants in the skills introduced himself and family

\begin{tabular}{|c|c|c|c|c|}
\hline \multirow[b]{2}{*}{ No } & \multirow[b]{2}{*}{ Name } & \multicolumn{3}{|c|}{ Understanding Level Score } \\
\hline & & $\begin{array}{c}\text { Before } \\
\text { Research }\end{array}$ & $\begin{array}{c}\text { After } \\
\text { Research }\end{array}$ & $\begin{array}{c}\text { Percentage } \\
\text { Enhancement }\end{array}$ \\
\hline (1) & (2) & (3) & (4) & (5) \\
\hline 1 & Ana Purwati & 50 & 70 & 40,00 \\
\hline 2 & Apriyanto Budi K. & 30 & 60 & 100,00 \\
\hline 3 & Nita Puspasari & 60 & 80 & 33,33 \\
\hline 4 & $\begin{array}{l}\text { Nawangwulan } \\
\text { Satu SR. }\end{array}$ & 60 & 70 & 16,67 \\
\hline 5 & Resgian Apri D. & 40 & 60 & 50,00 \\
\hline 6 & Teguh supriyanto & 60 & 70 & 16,67 \\
\hline 7 & Fazriyan adha & 70 & 80 & 14,29 \\
\hline 8 & $\begin{array}{l}\text { Dimas Ari } \\
\text { Setyawan }\end{array}$ & 80 & 90 & 12,50 \\
\hline 9 & Rully Wahyu H. & 60 & 70 & 16,67 \\
\hline
\end{tabular}

\begin{tabular}{llccc}
\hline 10 & Adnan Aulia M. & 60 & 80 & 33,33 \\
\hline 11 & Nanang Fitriyanto & 50 & 70 & 40,00 \\
\hline 12 & Muhammad Azis & 40 & 60 & 50,00 \\
\hline 13 & $\begin{array}{l}\text { Aisyah } \\
\text { Indrianingtyas }\end{array}$ & 80 & 90 & 12,50 \\
\hline 14 & $\begin{array}{l}\text { Anisa Retno } \\
\text { Hapsari }\end{array}$ & 80 & 100 & 25,00 \\
\hline 15 & Friska Apriliani & 70 & 80 & 14,29 \\
\hline 16 & $\begin{array}{l}\text { Fadillah Tri } \\
\text { Cahyanti }\end{array}$ & 60 & 70 & 16,67 \\
\hline 17 & Ernaningtyas DK. & 50 & 60 & 20,00 \\
\hline 18 & Indi Ayu Azhari & 50 & 70 & 40,00 \\
\hline & Amount & 1050 & 1330 & 551,92 \\
\hline & Average & 58,33 & 73,89 & 30,66 \\
\hline
\end{tabular}

Score 80-100 : very understand;

Score 50-70 : understand;

Score 40-60 : little understand;

Score 10-30 : don't understand.

\section{Discussion}

The demonstration/trial research activities onthe practice of introducing oneself and family and others are very beneficial for elementary school students especially the 3rd grade at SD Negeri Jombor 03 Bendosari Sukoharjo. This is related to the speaking skills of elementary students who are still far from expectations. This self-introduction skill needs to be mastered by students specialized in the competition for seats in class at the elementary level. Therefore this research activity really helped the participants. In general, this activity is very useful in daily communication. Introducing yourself becomes a mandatory topic when meeting new people. Especially now that many foreign tourists come to visit this city. The participants seemed enthusiastic in following the activities to the end. They seemed motivated to do all the instructions so that their speaking ability also increased.

This success is inseparable from the support of school principals, teachers and employees of SD Negeri Jombor 03. In addition, the participants' desire to master the speaking skills to introduce themselves and their families is quite large. This knowledge about introducing themselves has never been received by the participants, so they are very enthusiastic in participating in research activities.

In carrying out this research activity, the research team did the following:

1. Conducting preliminary observations or field orientation regarding the knowledge of students at SD 
Negeri Jombor 03 Bendosari Sukoharjo about knowledge of English. At the initial observation, the research team found that the speaking ability of Grade VI students was still far from expectations. This is seen from the recording of student grades that are still below the KKM.

2. Holding a pretest about the speaking ability of students at SD Negeri Jombor 03 Bendosari Sukoharjo in English. The results of the pretest show that the average ability of students is 58.33, which is included in the range of the slightly understood value category.

3. Providing practice in conversing about the ability to introduce yourself in English, including: greeting ( greeting), introducing yourself ( Introducing herself / himself), introducing family ( Introducing his / her family), introducing friends (Introducing his/her friends ) using LCDs, plastic boards, and letter cards. The learning procedure is as follows:

- The teacher explains the material with LCD media. Participants look more enthusiastic because the pictures are presented according to their world.

- The teacher distributes teaching aids in the form of plastic boards and letter cards.

- The teacher gives examples of simple greetings in everyday life

- The teacher writes greetings in English on a classic board in front of the class Students follow it by writing on a plastic board.

Example:

\section{Hello good morning}

Hello good afternoon

Hello good evening

Hello my name is Agung

- The teacher says greeting sentences written on a classical board several times and is followed by students

- After the students are fluent enough to say the greeting sentence, the teacher gives an example of a simple dialogue.

Example:

- This exercise is repeated until all the material is delivered.

4. Provide training to introduce yourself in English, including: introducing yourself (introducing himself/herself), introducing family (introducing his/her family), introducing friends (introducing his/her friends) in English independently (individually).

5. Provide training in introducing yourself in English, including: introducing yourself (introducing himself/herself), introducing family (introducing his/her family), introducing friends (introducing his/ her friends) in English in pairs (in pairs) .

6. Providing exercises to introduce themselves in English, among others: introducing themselves (introducing himself/herself), introducing family (introducing his/her family), introducing friends (introducing his/her friends) in English in groups (groups).

7. Conduct an evaluation of the ability of students to introduce themselves in English, including: introducing themselves (introducing himself/herself), introducing family (introducing his/her family), introducing friends (introducing his/her friends). In this evaluation students were asked to do a demonstration in front of the class, and it was proven that each student was able to perform well and their speaking ability showed improvement.

8. Hold posttest on the ability of students to introduce themselves in English, including: introducing themselves (introducing himself/herself), introducing family (introducing his/her family), introducing friends (introducing his/her friends). Posttest showed an increase of $30.66 \%$ ie from the previous pretest with a mean score of 58.33 increasing to 73.89 in the posttest. Thus the participants experienced an increase from the level of understanding to understanding. Despite the fact that there are already some students who are very understanding.

The inhibiting factor of this activity is relatively small, out of 18 students there appear to be 2 students who appear to be less interested in the material. They are busy with their own activities and even disturb other friends who are discussing. After taking a personal approach, the research team was able to return the students' attention to become more focused and begin to interact and work together with their respective group teams. Another problem arises when the media used by the research team turns out to be new to participants. This caused serious noise so that for a moment the class became very crowded. But the research team immediately took action such as saying hello and inviting children to clap loudly and in a typical rhythmic way to stop the noise.

The participants were happy because of the advanced technology, namely LCD and with media such as cards that they had never met before in teaching and learning

\begin{tabular}{l}
\hline Hello good morning \\
\hline How are you? \\
\hline Good morning \\
\hline I'm fine
\end{tabular}

activities. The research team obtained this information from the recognition of a number of students and from related teachers.

From the evaluation results about the research introducing yourself, and family that can be explained from table 3.1. The results of the pretest 
showed that the understanding of the participants before the study still lacked understanding of the material with a mean value of 58.33. and after carrying out research the average post test score was 73.89. This means that the participants' understanding of the material provided increased by $30.66 \%$. This shows that the research activities to the community succeeded in increasing the knowledge and skills of participants in introducing themselves and their families. This also shows that the participants in the study were very enthusiastic about wanting to increase their knowledge about introducing themselves and their families.

The output produced in this activity is, the ability of students of SD Negeri Jombor 03 Sukoharjo, especially grade 3 students in introducing themselves, family and friends in English independently, in pairs, and in groups can be done smoothly in front of the class without fear or shy.

\section{CONCLUSION}

Based on the results and discussion in chapter 5, the research team concluded that: The Study of Using Introduction Themselves and Their Families Conversations independently or in groups. In Teaching Speaking In Grade 3 SDN Jombor 03 Bendosari Sukoharjo, using simple conversation media, the results of teaching speaking students increasing, students become more enthusiastic and interested in learning and teaching English, especially speaking. With the skills of conversation also makes it easier for teachers to teach English. And the achievement of the material is easier than just an explanation. Besides teaching speaking through conversational skills, this makes students more interested and enthusiastic about learning English. The selection of appropriate material also greatly influences student achievement in learning speaking.

\section{Acknowledgements}

The research on the study of the use of conversation in teaching speaking in grade 3 students at SDN Jombor 03 Bendosari Sukoharjo is expected to provide detailed information to English language teachers elsewhere. By using simple conversation media in teaching speaking, teachers are asked to pay attention to the basic procedures in teaching English, especially teaching speaking.

\section{REFERENCES}

Ary, Donald. (1979). Introduction to Research in Education. New York : Holt, Rinehart and Winston.

Beck, Robert H. (1960). Curriculum in the Modern Elementary School. Pretice-Hall Inc. Engle Wood Cliffs.

Beckwith, Mary. (1968). The Effective Elementary School Teacher. New York : Parker Publishing Company, Inc., West Nyack.
Brown. N. Douglas. (1987). Principle of Language Learning and Teaching (Second Edition). New Jersey : Pretice-Hall, Inc.

Mackey, William Francis, (1965). Language Teaching and Analysis, London : Longman Group Ltd.

Dankin, Julian, (1985). Songs and Rhymes for The Teaching of English. Singapore : Longman Publisher Ptc. Ltd.

Depdikbud. (1991). Kurikulum Muatan Lokal Pendidikan Dasar. Semarang.

Hadfield, Jill. (1984). Elementary Communication Games. Hongkong : Nelson.

Hewings, Martin. (1999). Speaking Practice Through Interaction. Cambridge University Press.

Hewings, Martin. (1993). Speaking Tasks. Cambridge 